\title{
International Standard of Concert Pitch
}

\author{
By Dr. G. W. C. Kaye, O.B.E., F.R.S.
}

$\mathrm{T}$ HE question of the international standardization of concert pitch, to which reference has already been made in NATURE (November 5, 1938), was the subject of an International Conference on May 11 and 12 last, under the auspices of the International Standards Association (I.S.A.). The Conference, which was held at Broadcasting House by the courtesy of the British Broadcasting Corporation, was organized, at somewhat short notice, by the British Standards Institution under its director, Mr. Le Maistre. Five countries (France, Germany, Great Britain, Holland and Italy) sent delegates, while the official views of Switzerland and the United States of America were before the Conference. The International Union for Broadcasting (U.I.R.), and the International Consultative Committee on Telephony (C.C.I.F.) were also represented by delegates. The president of the Conference was Dr. G. W. C. Kaye, chairman of the British National Committee on Acoustics, and the British delegation consisted of Dr. Kaye, Dr. F. W. Alexander, Captain E. H. T. Broadwood, Mr. Ll. S. Lloyd and Mr. Henry Willis.

The Conference was formally opened by Sir Cecil Graves, deputy director-general of the B.B.C., who, after welcoming the delegates, pointed out that the fixing of a new concert pitch is a problem for the musician to decide, after which the aid of the technician must be sought to help the musician to use and maintain the pitch he has chosen. Although it is probable that the extreme range of variation of the pitch of orchestras the world over does not exceed a semitone, it was scarcely necessary to stress the increased comfort and assurance of a standardized pitch to singers and to players of concertos for stringed instruments. There is no doubt, too, that the manufacturers of musical instruments, particularly of organs and pianos, would welcome a standardization which would relieve them of the frequent necessity of re-tuning. As regards listeners to music, whether in the concert hall or through the medium of broadcasting, no real comparison on the score of brilliancy of two different performances of the same symphony by different conductors is possible unless the two performances are based on the same pitch. In these days of emotional stress, it is no small achievement for nations to come together to discuss a subject that is very much bound up with the emotional factor. General agreement on principles and practice might well be a promising portent for the future of the world.

In his opening address, the President reminded the delegates of the occasions in the past when agreement had been sought on the present question, but no outstanding measure of international unification had ever resulted. He hoped that before the Conference dispersed, it would have set up a musical milestone of lasting significance. The question of an international standard of concert pitch, while always of commercial importance in the international trading of musical instruments, has assumed a new prominence in view of the requirements of international broadcasting and the development of electro-acoustical instruments. It was in fact the urgent requirements of the International Broadcasting Union which finally led to the decision to endeavour to bring about international agreement.

After suggesting that the Conference should confine itself to the standard convention of expressing concert pitch in terms of the note $A$ in the treble clef, brief reference was made to the historical background of concert pitch-to the early and pronounced meanderings of pitch during the fourteenth to the nineteenth century; to the first attempt at standardization a century ago in Great Britain, namely, the philharmonic pitches of 433 in 1826 and of 455 in 1845 ; to the value, 440 , adopted by the Stuttgart Conference in 1834 ; to the French Diapason Normal, 435 , of 1859 , and its endorsement by the International Congress of 1885 in Vienna. In the United States, a figure of 440 is now general after many vagaries, while as regards Great Britain, reference may be made to the standardization at 439 of piano pitch by the piano makers in 1899 , and to the lowering in 1927 of the pitch of the British Army bands from 455 to 439 . The first question before the Conference was virtually that of reviewing the present general upward departure from the standard adopted in Vienna more than fifty years ago. Incidentally, so far as actual frequency measurements go, the standardization requirements of musical pitch present an easy problem to the physicist who can, if desired, measure frequency to an accuracy of 1 in 100 million.

A survey of the reports submitted by different countries to the Conference indicates that the present position can well be regarded as propitious for international agreement:

\begin{tabular}{|l|c|}
\hline & $\begin{array}{c}\text { Treble } A \\
\text { (cycles per sec.) }\end{array}$ \\
\hline French Standards Association, proposes & 440 \\
German Standards Association, proposes & 440 \\
American Standards Association, proposes & 440 \\
British Standards Institution, proposes & 440 \\
Dutch Acoustics Committee, agrees & 440 \\
Swiss Standards Association, agrees & 440 \\
International Union for Broadcasting, suggests & 440 \\
Italy has adopted & $435 \pm 4$ \\
Mean of European Concert Broadcasts & 443 \\
Electric organs, American & 440 \\
Electric organs, British & 439 \\
\hline
\end{tabular}

A friendly and vigorous discussion followed, during which it was happily found possible to establish eventual agreement on the main points at issue. Thereupon, taking cognizance of the general lack of observance of the Vienna standard (435) in favour of an appreciably higher though variable figure, which moreover shows a constant and regrettable tendency to increase, and having regard to the æsthetic, technical and economic importance of early international standardization within the limits of existing practice, the Conference unanimously agreed to forward the following recommendations to the parent International Acoustics Committee for submission to, with a view to ratification by, the national standardizing bodies affiliated to the International Standards Association; also to the U.I.R., the 
C.C.I.F. and the International Electrotechnical Commission (I.E.C.) :

(1) That the international standard of concert pitch shall be based on a frequency of 440 cycles per second for the note A in the treble clef. ("La normale".)

(2) That this value shall be maintained within the closest limits possible, by soloists, orchestras, choirs, etc., throughout all musical performances, and also in recorded music.

(3) That with a view to reducing the necessary tolerances to acceptable values, a set of technical recommendations be drawn up, preferably on the basis of international co-operation.

An appendix to the recommendations relates to a future programme of study designed for early discussion, so as to render effective as soon as possible the practical observance of the new standard concert pitch: for example, the differential influence of temperature on the various orchestral instruments and the consequential tuning adjustments before and during a performance; the feasibility of transmitting the standard pitch by means of broadcasting or telephone; the provision of sub-standards of pitch, portable or otherwise, and the advisability of their verification by an official laboratory; the production of specifications dealing with the appropriate tolerances in the manufacture of musical instruments; and the setting up of supervisory safeguards, both national and international, for verifying the observ. ance of the new standard pitch and so preventing the possibility of its falling into desuetude, as has occurred with the Vienna standard.

The success of the Conference was a happy vindication of the decision to go forward with the plans for bringing the delegates of the different countries together, despite the troubled nature of the times. The delegates further consorted in complete and amicable accord on the occasions of visits to the Acoustical Laboratory of the National Physical Laboratory by the kind invitation of the Director, and to Lyne, Capel, Surrey, at the invitation of Captain Broadwood, whose beautiful house and estate, in all the glory of the spring foliage, formed a lovely setting for his genial hospitality and the delightful unaccompanied old English melodies of the famous Tudor Singers under the direction of Mr. Cuthbert Bates.

\section{Telephony in the United States}

\section{$\mathrm{T}$} HE annual report by the directors of the American Telephone and Telegraph Co. for the year 1938 is of great interest. The taxes last year were equal to about 80 cents per month per telephone, which is about 14 per cent of the average telephone bill, or about one third of the total pay roll. Notwithstanding the heavy taxation and increased wages, the earned dividends for the last two years were nearly the same.

Until 1927, the longest distance a telephone call could be made was about 3,000 miles; to-day there is no limit. We can talk round the world. The improvement in transmission on a call from New York to San Francisco as compared with twenty years ago when trans-continental service was inaugurated is roughly equivalent to the difference between conversing in an open field at a distance of several hundred feet and conversing with someone in the same room at about one third the cost. Five years ago the time of making a long-distance connexion was reduced from $7 \cdot 5$ minutes to 3 minutes. Last year a direct radio telephone circuit from San Francisco to Australia was made, replacing the original route from New York via London. This new circuit is several thousand miles shorter and made possible a substantial reduction in the price of a call.

The ocean liner Nieuw Amsterdam has been added to those with which the Bell system operates shipto-shore radio telephone service. Twelve shore stations of the Bell system and its connecting companies now serve nearly a thousand small vessels on the Atlantic and Pacific coasts and on the Great Lakes.

The damage experienced by the destructive effects of fires, floods, tidal waves and hurricanes in 1938 was the most extensive ever experienced. In September all these destructive forces combined, causing a disaster in the eight north-eastern States affecting the greatest number of telephones and communities since the telephone was invented. More than half a million telephones were silenced, and 240 communities were isolated. The wreckage of telephone plant put the Bell system to the greatest test it had ever been called on to face-a test of the organization, of its men and women, and of its resources of equipment and supplies. More than 2,300 trained men with 615 motor-vehicles were loaned by fourteen telephone companies. Enormous quantities of materials were rushed in promptly by the Western Electric Co. The Bell companies in the stricken area, assisted by the resources of the entire Bell system, successfully met the challenge of the catastrophe, the telephone men and women, unmindful of hardship, carried on with resourcefulness and courage, and the result was an almost impossible job splendidly done.

Research in the field of radio telephone transmission has been specially pushed in the direction of increasing the efficiency and the steadiness of trans-oceanic circuits in anticipation of the adverse conditions likely to occur in 1940 and 1941 at the time of the expected maximum effect of sunspot disturbance. Highly efficient adjustable directional antennæ have been prepared. One of these, two miles long, is now being installed in the trans-Atlantic route. Two noteworthy achievements in civil and military aeronautics were made last year. One was the development of an accurate instantaneous terrain clearance indicator by which a pilot is at all times apprised of his height above the ground. The other was the development of an aeroplane locator for use at ground stations. By dialling the frequency of the aeroplane radio, the airport operator can see on a map the direction of any aeroplane within range. This should be of great value in reducing risks to aeroplanes in bad weather.

The Company has a memorial fund which provides annual awards in recognition of unusual acts of service. This year one (posthumous) gold medal with $£ 100$ and thirty-two bronze medals were awarded to individuals, and four special bronze plaques were awarded to groups of employees in recognition of their skill, courage and devotion to duty along the Ohio River Valley during the flood of January 1937. 